\title{
岩手県における野生動物の保護管理
}

\author{
山内貴義 \\ 岩手県環境保健研究センター テ 020-0852＼cjkstart岩手県盛岡市飯岡新田 1 地割 36-1
}

\section{Wildlife management in Iwate Prefecture}

\author{
Kiyoshi YAMAUCHI
}

Research Institute for Environmental Science and Public Health of Iwate Prefecture, Iiokashinden, 1-36-1, Morioka 020-0852, Japan

\begin{abstract}
Iwate prefecture is the largest area in Honshu Island, and much wildlife inhabits, this area. Asiatic black bears (Ursus thibetanus) inhabit almost all regions of Iwate prefecture; they make up a large part of Japan's black bear population. In the past, Sika deer (Cervus nippon) extensively inhabited the Tohoku region. Due to overexploitation and heavy snow from the Meiji Era to the beginning of the Showa era, their population suffered from a crash, and the distribution of the Sika deer population settled exclusively around the Mt. Goyo area. Japanese serow (Capricornis crispus) also decreased in number from over-hunting, and was declared a National Japanese Treasure as a protected species. However, because of agricultural and forestry damages caused by wildlife has become a social problem since the 1980's, owing to the increase of population size (of at least sika and serow) and/or the enlargement of distribution, the prefecture made the Specified Wildlife Conservation and Management Plans (SWCMP). The several monitoring projects which supply important information for carrying out the SWCMP are continuously conducted every year with the cooperation of many hunters. While continuing these monitoring projects, the prefecture has carried out appropriate wildlife management, but recently several problems have started to occur. First, it is difficult to estimate population size accurately. Secondly, there has been an enlargement of distribution, leading to more "wandering" into human communities. Furthermore, the number of hunters is decreasing remarkably. In order to solve these problems, the development of new monitoring methods, the control of distribution enlargement, and an approach that collaborates with local society to control wildlife damage, is needed.

Key words : monitoring method, the Specified Wildlife Conservation and Management Plans, wildlife damage control, hunter, wildlife management
\end{abstract}

Jpn. J.Zoo. WildI.Med. 13(1) : 1-8, 2008

\section{はじめに}

岩手県は本州で最も大きな面積を有している。県を縦断す る北上川と馬淵川周辺には平地が広がり, 人口密度が高いが, その両側には広大な山脈が存在している。太平洋に接する北上 高地はなだらかな山脈が連なっており, 有史以来, 放牧や薪材 の確保など多くの場所で人が山林を利用し，なりわいの場とし てきた。一方，秋田県にまたがる奥羽山脈は，急峻な地形が多 く, 多雪であり, 北上高地とは環境的にも植生的にも大きな違 いが見られている。

この様な特色の異なる森林を中心として, 現在も多くの野
生動物が生息している。大型野生哺乳類であり, 森林生態系の 頂点に立つツキノワグマ (Ursus thibetanus ; 以下, クマ) は, ほぼ県内全域に生息しており，日本の中でも非常に大きな個 体群を形成している。大型野生草食哺乳類であるニホンジカ (Cervus nippon；以下, シカ) は, かつて東北地方に広く分布 していたが [1]，明治期末から大正にかけての過度の狩粆圧 と豪雪によって個体数が急激に減少し, 岩手県南東部に位置す る五葉山周辺地域に生息地が限定されるほど分布が狭められた [2]。そのため岩手県ではさまざまな保護施策を実施して個体 数の回復を図っていった結果，1970 年頃から狩弾頭数も徐々 に增え始めている。ニホンカモシカ (Capricornis crispus ; 以 
下, カモシ力）は旧来から狩猟の対象となっていたが, 個体数 の減少が懸念されるようになり，1955 年（昭和 30 年）に特 別天然記念物に指定された。その結果, 現在では個体数が回復 し, 岩手県内のほぼ全域に生息している。ニホンザル（Macaca fuscata）は，かつて藩政時代に県内各地で捕獲された記録が 残っているが, 現在では県南東部に数群が確認されているだ けである[3]。岩手県内にもかつてはニホンイノシシ（Sus scrofa）が広く生息していたが, 過度の狩猟圧によって明治時 代に絶滅している。

以上のように岩手県にはさまざまな野生哺乳類が生息して おり, 旧来から人と共存を続けてきた。しかし近年, クマやシ 力, 力モシ力などの大型野生哺乳類は生息数が増加し, 人里に 出没して農業や林業に多大な被害を及ぼすようになった。クマ は 1970 年代から農業被害の増加によって有害捕獲が行われる ようになり，1980 年代では急増している。ここ数年間では狩 猟頭数よりも有害捕獲頭数が圧倒的に多くなっている。有害捕 獲頭数の増加はクマ個体群に与えるインパクトが大きく, 個体 数の減少が危惧されている。シカも 1980 年代から農林業被害 が深刻になって社会問題化したため, シ力被害対策が 1990 年 代から進められている [4]。カモシ力は特別天然記念物とし て保護されたことで個体数が増加し, 昭和 40 年代から造林地 での食害が顕著になり始奴また最近では農業被害について も報告されるようになり, 社会問題化している。この様な状況 の中で 1999 年 (平成 11 年) に鳥獣保護及狩猟二関スル法律 (現在の鳥獣の保護及び狩編の適正化に関する法律)が改正され, 野生動物の保護管理（Wildlife Management）という概念によ る特定鳥獣保護管理計画制度（以下,特定計画）が創設された。 岩手県では個体群の維持と被害の低減を目指して, クマ, シカ, カモシ力で特定計画が施行されている。本稿では特定計画を実 行するうえでのモニタリング調査について解説し, 特定計画を 遂行するうえで生じた問題点ならびに今後の課題について論じ
たい。

\section{モニタリング調査について}

これまで特定計画を遂行するうえでさまざまなモニタリング 調査が行われてきた。表 $1 \sim 3$ にクマ, シカ, カモシ力のモ ニタリング調査項目と実施内容を示した。シカのモニタリング 調査は歴史が最も長く, 1980 年（昭和 55 年）から高槻成紀氏 (現所属; 麻布大学) によってササ調查や捕獲個体調查（胃内 容分析, 腎臓脂肪の分析による栄養状態の評価など）が開始さ れた [2]。その後, ヘリコプター調査や生息密度調查などの 大規模なモニタリング調查手法が導入されていった $[4]$ 。岩 手県の事業としては, 1988 年度（昭和 63 年度）から現在ま で継続して行われている [5-7］。この岩手県の取り組みは日本 の中でも先進的であり, 保護管理のモデルとして位置づけられ るようになった。特に捕獲個体を個体群管理のためのサンプル として活用した事例は, 現在では多くの動物種や地域で応用さ れており，日本におけるモニタリング調査の基礎を築いたとい える。クマは 1987 年（昭和 62 年）から 3 年間にわたり, は じめて県内全体を対象とした大規模な調查が実施された。調查 項目は生息分布調查, 生息数調査および捕獲個体調査などであ った。また人里に出没して農作物に被害を与えた個体に学習付 け（おしおき）をしたうえで奥山に放獣する「移動放獣」を， 1998 年 (平成 10 年) から 3 年間にかけて試験的に実施し, その侵出防止効果の検証を行っている $[8]$ 。この時に始まっ た捕獲個体調査は, 現在も継続して取り組まれている。クマの 生息数調査は過去 3 回行われており, 最近では 2006 年（平成 18 年) に実施された。力モシ力は 2005 年 (平成 17 年) か ら特定計画が始まり, 表 3 のモニタリング調査項目が継続さ れている。

表 1 岩手県におけるツキノワグマのモニタリング調查

\begin{tabular}{|c|c|}
\hline 調查項目 & 検査内容 \\
\hline 個体情報調査 & ・捕獲記録を収集し，体重や性別，子の有無を把握 \\
\hline 生息分布調査 & - 狩猟者等からの捕獲報告等を基に生息分布域を把握 \\
\hline 被害実態調查 & • 人身被害や農林業被害の場所, 状況および金額などを把握 \\
\hline 捕獲個体調查 & $\begin{array}{l}\text { ・捕獲個体から分析試料を確保し, 繁殖状況, 年齢, 栄養状態 } \\
\text { 执よび食性などを把握 }\end{array}$ \\
\hline 行動圏調査 & $\begin{array}{l}\text { • 学習付け移動放獣した個体の回帰状況, 再被害防止効果, 行 } \\
\text { 動圈の範囲を把握 }\end{array}$ \\
\hline 堅果類豊凶調査 & ・堅果類の結実状況を把握 \\
\hline 生息状況調査 & ・観察調査などによる生息数を把握 \\
\hline
\end{tabular}


表 2 岩手県におけるニホンジカのモニタリング調査

\begin{tabular}{|c|c|}
\hline 調査項目 & 検査内容 \\
\hline 捕獲数の把握 & ・狩猟および有害捕獲の報告票から捕獲頭数を把握 \\
\hline 生息分布調査 & ・目撃情報や捕獲情報をもとにシ力の分布状態を把握 \\
\hline 被害実態調査 & ・農林業被害状況扢よび被害防除対策の実施状況を把握 \\
\hline 生息密度調査 & ・追い出し法や糞塊法による生息密度を把握 \\
\hline 捕獲個体調查 & $\begin{array}{l}\text { ・狩猟抢よび有害捕獲個体から分析試料を確保し, 繁殖状況, } \\
\text { 年齢, 栄養状態扔よび食性などを把握 }\end{array}$ \\
\hline ササ調査 & $\begin{array}{l}\text { ・冬期のシカの重要な餌資源であるミヤコザサ（Sasa } \\
\text { nipponica）の採食状況を把握 }\end{array}$ \\
\hline 生息数調査 & ・ヘリコプターからの目視探查による生息数調查 \\
\hline
\end{tabular}

表 3 岩手県におけるニホンカモシカのモニタリング調査

\begin{tabular}{cc}
\hline 調查項目 & \multicolumn{1}{c}{ 検查内容 } \\
\hline 生息分布調査 & ・滅失届の情報（死亡個体の発見位置）を基に生息分布を把握 \\
被害実態調査 & ・農林業被害状況の把握抽よび被害防除対策の効果検証 \\
生息密度調査 & ・被害地域において区画法による生息密度を把握 \\
捕獲個体調查 & $\begin{array}{c}\text { ・捕獲個体から分析試料を確保し, 繁殖状況, 年齢, 栄養状態 } \\
\text { およよび食性などを把握 }\end{array}$ \\
\hline
\end{tabular}

\section{モニタリング調査における狩猟者の貢献}

モニタリング調査を実施するためには狩猟者の協力が必要不 可欠である。例えば狩猟者は狩猟捕獲または有害捕獲した個体 を解体し，サンプルを環境保健研究センターに送付している。 そしてその狩猟者が採取したサンプルは, 環境保健研究センタ 一や岩手大学，盛岡市動物公園で分析され，県自然保護課が分 析結果をとりまとめて特定計画に運用されている。また生息数 調查にも狩猟者の協力は欠かせない。シ力で実施されている生 息密度調査は, 狩猟の時に実践する追い出し法を応用している。 つまり「勢子」と呼ばれる人員が空砲や叫声によってシ力を調 查区内から追い出し, 調査区内を取り囲むように配置された「夕 チ」（この場合は観察者）が勢子によって追い出されたシ力の 個体数，性および大まかな年齢構成を記録する。著者は 2001 年からこの調査に参加しているが，トランシーバーを用いて勢 子の進み具合を確認しながらシ力をタチの方へ追いやる様子を 見ていると，地元の山に詳しく，また動物の行動を熟知してい る地区猟友会のメンバーでなければこのような調査は成し得な いと，毎年害感させられる。またクマで害施されている観察調 查にも狩猟者の技術が生かされている。これは調査地の一部を 地区猟友会のメンバーが踏査し，クマを直接観察する方法であ
る。しかし個体を実際に確認する事は非常に困難であるため, 足跡，爪痕抢よび蕒などの痕跡を探索している。そのため地勢 に詳しいばかりではなく，動物の行動や生態に精通していなけ れば生息密度が低いクマの痕跡を見つけることは困難である。 この他にも捕獲報告（体重や体長などのデータ）や，出猟した 時のシ力の目撃数 [9] など，さまざまなデータを狩猟者から 収集しており，モニタリング調查に狩猟者の協力が久かせない ものとなっている。

以上のように岩手県ではクマ，シ力，力モシ力の特定計画を 進めるにあたり，狩猟者の協力のもとにモニタリング調查を継 続しながらフィードバック管理を行い，適切な保護管理の実施 を目指している。しかし近年，これらのモニタリング調査を行 うにあたりさまざまな問題や課題が発生している。以降はそれ らの問題点について整理してみたい。

\section{正確な生息頭数の把握}

モニタリング調査における最大の問題として, 正確な個体 数を推定することが非常に困難である点が挙げられる。クマ の生息数調査は, 1989 年 (平成元年) と 2001 年 (平成 13 年), 2006 年 (平成 18 年) の過去 3 回実施された。そのう ち, 1989 年と 2001 年の調査では, 推定生息数がそれぞれ約 


\section{山内貴義}

1,000 頭と 1,100 頭として発表された $[10,11]$ 。調査方法は 調査区画の一部を踏査する「観察調査」である $[12,13]$ 。この 観察調査は岩手県のような広大な面積を短期間で調査するに は最も都合が良いと考えられる。しかし踏査中にツキノワグマ を発見することはまれであり，そのため覜や足跡などの痕跡情 報から生息数を算出している。岩手県の場合, 調査区内に痕跡 が幾つあっても, その区画は 1 頭として取り报っているため, 生息頭数を過少に評価している可能性が高く，観察調查による 精度の限界と判断できる。

また個体数の変動予測を行うシミュレーションの精度にも問 題がある。生息数調査は通常，数年おきに実施されている。そ のため調査が行われない年にはシミュレーションなどによって 個体数の变動予測を行い, 毎年の捕獲上限数（有害捕獲頭数十 狩猟頭数）を決定している [11]。しかし観察調査で推定され た当初の生息数が過少であるためにシミュレーションによる推 定頭数が少なくなり，捕獲上限数も減少してしまっている。し たがって生息数推定法の精度を向上させる抜本的な改良が必須 である。

シ力の場合, 五葉山周辺地域のヘリコプターによる生息数調 査が 1993 年 (平成 5 年), 1997 年 (平成 9 年), 2000 年 (平 成 12 年), そして 2007 年（平成 19 年）往実施された。生息 数の推定值は, 1993 年時点で $5,400 \pm 900$ 頭, 1997 年時点

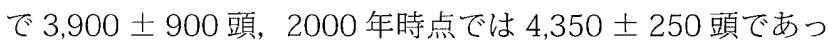
た。2007 年に行われた推定生息数は，3,976士658 頭であ り, 生息数としては前回調査と比較してほぼ横ばい状態であ ると判断できる。落葉広葉樹林帯において，落葉期かつ積雪時 に行うへリコプター調査は, シ力個体数を調査する方法として 有用であると考えられている。しかし，常緑針葉樹林に潜むシ 力は上空からほとんど確認することができない。またへリコプ ター調查では見落としが発生する可能性も高いため, ペテルセ ン法 [14-16］によって見落とし率の補正を行っているが，条 件の良い落葉広葉樹林带においても高い見落とし率が発生する 可能性も示されている。そのため実際の生息数よりも過少に算 出されている可能性が高いと考えられる。さらに，シ力生息数 調查の結果を受けて, SimBambi [17］による生息数推移のシ ミュレーションが行われているが，この精度にも問題が生じて いる。2000 年のヘリコプター調查の結果から SimBambi によ る生息数の推移を予測したところ, 毎年 1,000 頭以上の捕獲 を続けていたため推定生息数は減少傾向に古るという結果が出 された。しかし農業被害は増加傾向にあり，また追い出し調査 やササ調査の結果からシ力密度がシミュレーションどおりに減 少していないことが示された。これは当初算出した生息数が過 少であることと，シミュレーションの計算方法が現状から北離 していることが原因であると考えられ，これらの精度を向上さ
せるための方策が必要である。

カモシカの生息数調查はこれまで被害が発生している地域を 中心に行われている。調查方法には通常, 区画法などが用いら れるが [18], 岩手県ではシカと同様に追い出し調查を行って 生息密度を算出した。2004 年の調査結果では, 大船渡市で平 均 1.52 頭 $/ \mathrm{km}^{2}$ (4 か所), 陸前高田市で平均 4.42 頭 $/ \mathrm{km}^{2}$ (4 か所), 住田町で平均 2.08 頭 $/ \mathrm{km}^{2}$ (4 か所), 遠野市で平均 5.46 頭 $/ \mathrm{km}^{2}$ (4 か所), 釜石市で平均 1.72 頭 $/ \mathrm{km}^{2}$ (4 か所), 大槌町 3.28 頭 $/ \mathrm{km}^{2}$ (4 か所), 盛岡市 1.30 頭 $/ \mathrm{km}^{2}$ (2 か所) であり, 全体で平均 2.76 頭 $/ \mathrm{km}^{2}$ （26 か所）であった。この 手法では調査地域の生息密度は示されるが, 県内の殆どの山林 にカモシカが生息しているため県内全体の頭数まで把握するこ とは不可能である。シ力では狩弾統計や目撃効率などのデータ が個体群動態の指標として用いられているが [9], カモシカ の場合, 特別天然記念物であるためこれらのデータも存在して いない。つまり, 現状では被害地域（個体数調整を実施する地 域）の生息密度は明らかになっているが, 全体の生息数の把握 は不可能な状況である。

以上のように, 野生哺乳類の生息数を推定することは非常に 困難であり, 特定計画を推進するうえで最大の懸案事項といえ る。

\section{生息域の急激な拡大}

クマ, シカ, カモシカともここ数十年の間に生息分布を急速 に拡大している。1978 年に当時の環境庁から発表された自然 環境保全基礎調査では, 岩手のクマは北上高地と奥羽山脈を中 心に分布し，人口密度が高い北上盆地ならびに北上高地の北部 と南部には分布が茪られていない [19]。しかし 2003 年の同 様の調查では, 前回までに分布が認められなかった地域にも生 息が確認されており， $5 \mathrm{~km} \times 5 \mathrm{~km}$ メッシュ数で 1.2 倍にまで 増加している [20]。つまりこれまでは高標高地域に分布して いたが，人里に近い低標高地域まで広く分布するようになった ことを意味しており，新たな問題を引き起こしている。2006 年度にクマの大量出没が全国的に発生したことは記憶に新し いが，岩手においても北奥羽地域において里への出没が増加 し, 有害捕獲頭数が急増した。例年であれば有害捕獲頭数は 秋以降に減少するが，2006 年は 10 月になっても出没や被害 が収まらず，有害捕獲が相次いだ。秋にも出没が増加した原因 としては, 森林内のブナの結実不作が一因として挙げられてい る[21]。また有害捕獲が多く行われた人里において, リンゴ 園の周辺各所に廃果が捨てられていた例もあることから [22], 人間の不適切な行動が森林内のクマを人里におびき寄せ, 過剰 な有害捕獲頭数に結びついた可能性も考えられる。さらに里地 里山の荒廃によって放棄された農地が拡大している集落では, 
高茎草本が生い茂り,そこに身を隠して容易に人里まで降りて くる個体も多くなると思われる。いずれにせよ, クマの大量出 没によって, 農業被害防止ばかりではなく, 人身被害の防止も 兼ねた早急の対応が求められている。

岩手県のシ力分布は, 1978 年には五葉山周辺地域にほぼ限 られていたが [19], 2003 年には約 3 倍にも増加して北上高 地全体に分布が拡大している [20]。シ力は雪に弱いため分布 は積雪量と関係があると考えられており [2], 近年の温暖化 による影響によって積雪量が減少し，これに乗じて分布を拡 大させたと推察できる。現行のモニタリング調査では主に五葉 山地域を対象として実施してきたため,このような急激な分 布拡大の情報を把握できていなかった。したがって今後は拡散 個体の生息状況をいかにモニタリングするかが新たな課題とな っている。そして生息域の拡大に伴い, 農業被害の増加が発生 している。シカの農業被害は 2001 年度 (平成 13 年度) から 2005 年度で約 1,300 万円から約 6,500 万円に増加した。この 理由はシ力の生息分布が拡大したためと推察されたが，詳細に 調べてみると五葉山地域以外のシ力拡散地域での被害金額はむ しろ減少しており, 従来から保護管理対策を続けている五葉山 地域での被害金額が急增していることが明らかとなった。内訳 を見ると, 水稲や野菜への食害が増加している。シ力生息密度 調査（追い出し調査）の結果を見ると, 五葉山地域において急 激な生息密度の上昇は確認されておらず，また被害作物はいず れも集落周辺で栽培されていることなどから, 従来の行動様式 が変化して五葉山地域の里に出没, または定着する個体「里ジ 力」が増えたことが農業被害の増加を引き起こしている可能性 が考えられた。

カモシ力も同様に 1978 年と 2003 年を比較すると生息分布 が拡大している。岩手県では $5 \times 5 \mathrm{~km}$ メッシュで区分された 90\%以上の区画にカモシ力が生息している [20]。1955 年以 前の分布が過去の資料から調査されているが [23], 当時の分 布は高標高地域に限定されている。特別天然記念物としての保 護のもとに分布を拡大させ, さらにここ数十年の間に過疎化が 急速に進行して管理されない里山や放置された農地が散在する ようになり, 生息分布を人里へ拡大させた可能性は十分にあり 得る。分布の拡大が農業被害の増加を招く結果となっているが, カモシカの場合は狩猟による捕獲が不可能であることから, ま ず被害詨策を進める施策が必要であろう。

\section{狩猟者の減少}

全国的に狩猟者の数が減少している。岩手県においても例 外ではなく, 急激な減少が認められる。図 1 に岩手県におけ る第一種狩猟者登録数の推移を示した。第一種狩猟者とは乙種 狩猟免許と同等であり, 散弾銃, ライフル銃などの銃器が使用

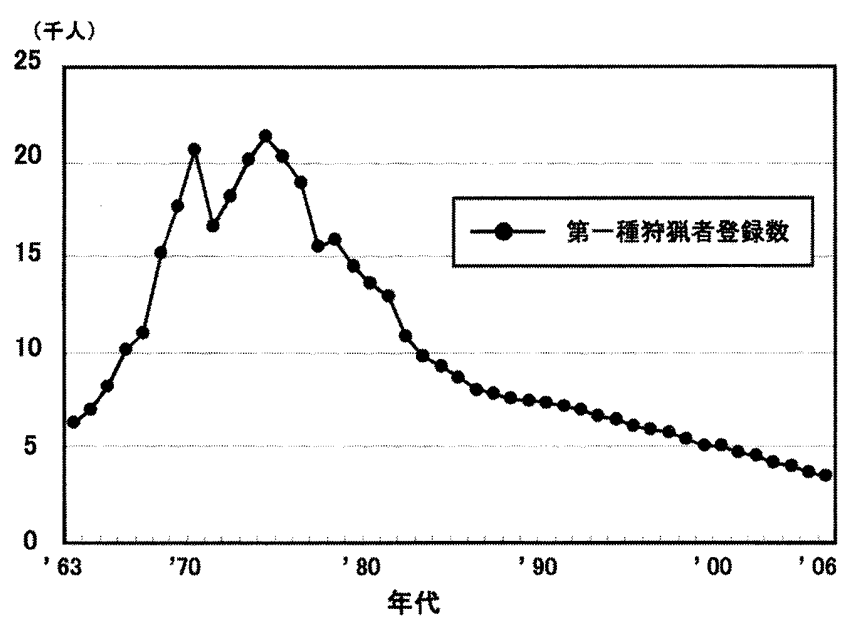

図 1 岩手県における第一種狩弾者登録証交付状況推移

できる免許種である。岩手においても一時期は 2 万人以上い た登録者数が現在では 3,500 人まで減少し続けている。また 年齢構成ではその殁どが 50 歳以上と高齢化が著しく進んでお り, 今や狩編者そのものが希少な存在となりつつある。したが って, 狩猟者の協力が不可欠な鳥獣保護行政に対して甚大な影 響が及ぶことが懸念されている。シ力では, 有害捕獲の他に, 増えすぎた個体数を狩猟によって減少させる施策が行われてき た。つまり個体数調整という公益的な役目を，スポーツハンテ イングという，いわば趣味の活動に対して過度に頼り続けてき た。狩猟者が多い時代には猟期の短縮や捕獲頭数の制限が行わ れていたが，現在はその規制を緩和させる方向に進んでいる。

また年によって違いが見られるが, 岩手県の第一種狩猟者 登録数の半数近くは県外の狩猟者であり, 地元の狩猟者数は非 常に少ない。つまり有害捕獲を行う人員の確保もままならない 状態に成りつつある。人間の生産活動の場所と野生動物の生息 地が隣接する地域では, 被害防除の網をかいくぐって常習的に 農産物を加害することを学習してしまう個体が高い確率で出現 することから, 最終的には捕獲によって排除する選択も必要と なる。クマの有害捕獲法は, 捕獲檻を毎日見回る必要があるた め, 非常に手間がかかると同時に, 狩猟者が長年の経験で培つ た技術が要求される。またワナ免許の取得も基準として示され ているため,地元で有害捕獲を実施できる人材は限られている。 狩編者人口の激減は, 狩猟者が行う地域への貢献活動の停滞を 引き起こす可能性がある。

前述したように，岩手県の場合にはモニタリング調査を行 ううえでも狩猟者の協力が不可欠であることから, 狩猟者の減 少は特定計画を遂行するうえでも大きな影響を与えるものと思 われる。 


\section{提起された問題点の克服と今後の取組み}

以上のように, 岩手県におけるクマ, シ力, カモシ力の保護 管理の現状から問題点が提起された。特に個体数を正確に推定 することは非常に困難であり, 最大の奬案事項といえる。クマ は生息密度が低く, 生活圏が森林内であるために個体の発見が 難しく, シ力で頻用される目撃効率や捕獲効率の解析 [9] を 応用することは難しい。農林業被害と個'本数変動との関連性 も不明であり，出没などの目撃数も情報収集に偏りがあって 信 憑性が低い。このような状況の中, 近年新たな個体数推定 法としてへア・トラップを用いた手法が欧米で開発されてい る [24-27]。ヘア・トラップ法による生息数推定とは, クマ の体毛を回収する装置（林内にクマの慨を吊し，その周りの 樹木に有刺鉄線を張り巡らせるトラップ）を設置し, 回収した 体毛から DNAを抽出して分析することによって個体識別を行 い, クマの生息数を算定する手法である。欧米ではへア・トラ ップに関する技術的な実験が繰り返し検討され，実用化の段階 まで研究が進んでいる。日本では生息数推定のための画期的な 手法として期待され, 幾つかの地域で試みられた。しかし急峻 な地形が多いことや，国有林・民有林を含めた土地所有者の協 力が得られないこと, さらにトラップの設置と遺伝子分析に高 額な費用がかかることなどの理由から, 欧米のような適切な研 究デザインが設定できず，応用段階まで進展していない。その ため日本でのへア・トラップの適用に否定的な意見も少なくな い[28］。岩手県では 2004 年から環境保健研究センターが中 心となってヘア・トラップ調査を行い, モニタリング調查に応 用すべく検討を続けている。現在のところ最少確認頭数の把握 に止まっているが, ヘア・トラップ調查の結果からこれまでの 痕跡に頼った観察調査の結果が過小評価であったことが示され ている。現在, 日本の研究者は日本独自のヘア・トラップ法を 模索しながら生息数推定へのさまざまな課題に取り組んでいる ところであり，今後の技術開発に期待したい。

これまでのシカのヘリコプター調査は, 針葉樹の人工林には シカがいないものとして頭数推定を行っているが, 実際には人 工林にも生息は確認されている。三浦ほか [29] は, 人工造 林地とその他の地域においてシ力の生息状況が変わらないと仮 定した場合，推定頭数がどの程度増加するかを試算している。 今後はへリコプター調查による個体数推定に，このような検 討を加味する必要があるだるう。また SimBambi の課題として 個体の移出入の問題がある。SimBambi では個体群は個体の移 出大がないと仮定しているが, 近年のシ力の分布拡大から判断 すれば，これは現実的ではない。したがって SimBambi の計算 式の改良を検討すべきであると思われる。さらに SimBambi で 使用している年齢構成, 生存率および妊娠率などのデータは過
去のものを採用しているために実態に対応していない [29]。 捕獲個体調査では狩猟によって捕獲された個体が主体である が, 今後は有害捕獲サンプルも積極的に回収してデータ化し, SimBambiに活用すべきである。

近年, クマやシ力, カモシ力の生息域が急速に拡大し, 人と 野生動物の距離が接近している。そのため人里へ出没する個体 が増加し，農業被害などを引き起こしている。2006 年は奥羽 地域に扔いてクマが大量出没し, 多くの個体が有害捕獲として 殺処分された。そこで盛岡市農政課は 2007 年度から有害捕獲 が増加した地区において積極的な被害防除への取組みを実施し た。取組み内容としては, 果樹園周辺の刚り払いや被害防除の ための電気牧柵の設置などであり，地元農家や岩手大学と共同 で実施している。2007 年度はクマの出没が全国的に少なく, この取組みに対する効果は明らかにされていないが, 前述した ように, 農家による廃果の不適切な処理や耕作放棄地の草原化 など，人が原因となって大量出没を招いている可能性も否めな いことから，これらの取組みは根気強く行っていく必要がある だろう。シ力では生息域の拡大に伴い, シ力がいなかった地域 において新たな被害が懸念されている。そのため新しいモニタ リング調查手法の導入が急務である。シカが分布を拡大させて いる地域にもへリコプター調査を行うことは予算的に不可能で あるため，比較的簡便に，かつ低コストでシカの密度が推定可 能な「糞塊密度調査」[30,31] 2004 年から開始し始めた。 これは尾根上を踏査し, シ力の翼塊数をカウントする調查法で あり，毎年継続して実施することで個体数の増減（トレンド） を追跡できることが明らかにされている [31]。2005年に行 われた結果からは, 追い出し調査によるシ力の生息密度と, 糞 塊数に比較的高い相関が示された [32]。一方, 急激な農業被 害の原因と推察される「里ジカ」の対策として，大船渡振興局 は 2004 年から 2 か年にわたり，「ニホンジカの農林業被害対 策基礎調査」を実施した。この調査では大船渡市三陸町の大野 地区と中井地区をモデル地域として被害実態調査, 生息状況を 探る糞塊密度調查とライトセンサス調査, GPSテレメトリーに よる行動特性調査などを実施した $[33,34]$ 。糞塊密度調査の 結果から，民家の裏山で五葉山保護区と同程度の糞塊数が確認 されている。またライトセンサスや GPS テレメトリー調査の 結果から, 夜間田畑に出没しているが，日中は近隣の山林内に 留まっている行動が示された。さらに 1 年中人里周辺で生活 している個体や，里の農作物が無くなる期間には近くの牧場を 利用する個体など，人里を中心とした生活様式が明らかにされ ている。これらの調査結果を受けて2005 年度から「里ジカ対 策」として定期的に集落内の薮の刚払いや防護柵のメンテナン スを行っている。また森林と農耕地との緩衝地带の創出を目的 とした休耕田への牛の放牧や, 道路から里へのシ力の侵入を防 
ぐ「グレーチング」の設置, さらに河川からのシカの侵入を防 ぐ電気柵の設置も行われた。その結果, シ力出没の減少が確認 され, 農業被害も減少した。この事業は, これまで調查の主た る対象ではなかった「里ジカ」に対する被害対策を検討したこ とによって画期的な成果をもたらしたといえる。しかしこの事 業の最大の成果は, 事業を進めるうちに地域住民のシ力対策へ の意識に変化が生まれ，刈払いや防護柵のメンテナンスを自発 的に行うという気運が生じたことであろう。

現在, シカの生息域が拡大している地域では目立った被害額 の増加は見られていない。2002 年度 (平成 14 年度) から岩 手県は生息域の拡大を抑制するために, 五葉山地域（大船渡市, 釜石市，陸前高田市，住田町）以外の侵出抑制地区において, 狩猟期間の延期と捕獲数制限を緩和した。しかし計画の指定範 囲外の地域（盛岡市など）に抽てもシ力の目撃情報が多く寄 せられ, 分布拡大阻止の効果が得られていないため, 第三次シ 力保護管理計画では岩手県全土を計画対象地域に指定し, 猟期 の延長と捕獲数制限の緩和を行引予定である。ところが狩猟者 が減少を続けている中，この対応策だけで分布拡大の阻止を期 待するのは難しいだろう。岩手県では大を用いたシ力猟が禁止 されており，そのため狩編者は追い出し法による熟練した連係 プレーによってシ力を捕獲している。したがって, シ力捕獲の ための人数が確保できない状態になれば, 捕獲数の増加は期待 できない。犬を用いたシ力猟に関してはさまざまな反対意見も あり現段階では緩和の見通しすら立っていないが, シ力の分布 拡大のスピードを考えると, 次に打つ手段として考慮すべき検 討課題であると筆者は考える。

これまで岩手県が実施してきたモニタリング調查は, ヘリコ プター調査に代表されるように, 広い領域を調査し, 総量的に 生息頭数を算出するものであった。しかし生息分布の急速な拡 大や人里への出没, 里ジカの増加など新たな野生動物の行動変 化にこれまでのモニタリング調査が対応できていない感は否め ない。そのため今後は総量的な調查に加えて, 地域の特性を活 かした調査・対策を取り入れる必要があるだろう。大船渡市で は 2007 年にシカ対策協議会を発足させ, ワナ免許の研修会へ の锥誘や手続きの取りまとめを促進させており,さらに県はワ ナ免許取得のための講習会の回数を増やすなどの対応をとって いる。つまり, 里ジカのような野生動物に対して柔軟に対応す るための方策として，または狩編者の減少を穴埋めするための 代替案として考え出された。今後は我々研究者も地域と一体に なって, 被害要因の解析や, 効果的な防除法, 捕獲法の開発, およびモニタリング手法の開発を検討し, 普及させていく必要 がある。

野生動物の保護管理には研究者の役割が大きい。特に個体数 の推定法は現在のところ確実な方法がなく, 新しい手法の開発
は篡嗸の課題である。しかし日本では野生動物の保護管理に携 わる研究者は非常に少なく, 欧米と比較すると遅れをとってい る。それはこの分野に関わる大学が少なく, 学生の数も少ない ことが起因しているのだろう。野生動物の保護管理に関わる問 題は山積している。今後この分野の人材を育成するために, 若 い研究者の積極的な活動の場を広げていく必要があるだろう。

\section{要 約}

岩手県は広大な面積を有し, 多くの野生動物が生息してい る。ツキノワグマは, 岩手県のほぼ森林全域に生息し, 国内で も非常に大きな個体群を形成している。ニホンジカはかつて東 北地方に広範囲に生息していたが, 明治期からの乱獲と豪雪に よって生息数が激減し, 五葉山周辺のみの分布となった。二 ホンカモシ力も過去の乱獲によって個体数が減少し, 特別天然 記念物として保護されている。ところが 1980 年代頃からこれ らの動物による農林業被害が深刻化したことから, 岩手県では 特定鳥獣保護管理計画（以下，特定計画）が施行された。特定 計画を遂行するうえで重要な情報を提供するモニタリング調査 は, その多くが狩猟者の協力のもと毎年継続して実施されてい る。これらの調査を継続しながら適切な野生動物の保護管理を めざしているが, 正確な生息頭数を把握することが非常に困難 であること，また生息域が急激に拡大して人里への出没が増加 していること, さらに狩弾者が激減していることなど, さまざ まな課題も発生している。これらの問題を克服するためには, 新たなモニタリング調査技術の導入, 分布拡大の抑制といった, 地域と一体になった取組みを推し進める必要がある。

キーワード：野生動物保護管理, モニタリング調査, 特定 鳥獣保護管理計画, 鳥獣被害対策, 狩猟者

\section{引用文献}

1. 遠藤公男. 1994. 盛岡藩御狩り日記一江戸時代の野生動物誌. 講談社, 東京.

2. 高槻成紀. 1992. 北に生きるシ力たち. どうぶつ社, 東京.

3. 岩手県. 2001. いわてレッドデータブック，岩手県生活環境部自然保 護課, 盛岡.

4. 高柣成紀 編. 1998. 五葉山のシ力調査報告書. 岩手県生活環境部自 然保護課, 盛岡.

5. 三浦慎悟. 1998a. ニホンジカ管理のモデルとしての岩手県・五葉山 個体群 (I ). 森林総合研究所東北支所たより 440: 14 .

6. 三浦慎悟. 1998b. ニホンジカ管理のモデルとしての岩手県・五葉山 個体群 (II). 森林総合研究所東北支所たより 441: 14.

7. 三浦慎悟. 1998c. ニホンジカ管理のモデルとしての岩手県・五葉山 個体群 (III). 森林総合研究所東北支所たより 442: 14 .

8. 岩手県生活環境部.2001。ツキノワグマ保護管理対策事業報告書〜移 動放獣マニュアル〜，岩手県環境保健部自然保護課，盛岡.

9. 宇野裕之, 横山真马, 坂田宏志, 日本哺乳類学会シ力保護管理検討作 
業部会. 2007. ニホンジカ個体群の保全管理つ現状と課題. 哺乳類科 学 47:25-38.

10. 岩手県環境保健部.1991。二ホンツキノワグマ生息実態調査報告書. 岩手県環境保健部自然保護課．盛岡。

11. 岩手県. 2003. ツキノワグマ保護管理計画. 岩手県環境生活部自然 保護課, 盛岡.

12. 林 知久夫. 1991. 生息数調査. 岩手県二ホンツキノワグマ生息実 態調查報告書. pp.12-21. 岩手県生活環境部自然保護課, 盛岡.

13. 林 文. 1997. 観察発見確率法の例一ツキノワグマー。 森林野生 動物の調查一生息数の推定法と環境解析一(禁林野生動物研究会編), pp. 192-208. 共立出版株式会社, 東京.

14. 大井徹, 鈴木一生, 堀野蒖一, 三浦慎悟. 1993. ニホンジカの空中 カウントと地上追い出しカウントの比較. 哺乳類科学 33: 18.

15. 大井徹, 堀野真一, 三浦慎悟. 1998. ヘリコプターか50目視探査に よる生息数調查. 五葉山のシ力調查報告書（1994～1997 年度）（高槻 成紀編), pp.19-27. 岩手県生活環境部自然保護課, 盛岡.

16. 大井 徹, 堀野真一, 三浦慎悟. 2002. ヘリコプターからの目視探查 に上る生息数調查. 五葉山のシ力調查報告書（1998～2001 年度）(高 槻成紀編)，pp.2328．岩手県環境生活部自然保濩課，盛岡。

17. 堀野犋一・浦慎悟. 1998. シ力個体群とシミュレーション. 五葉山 のシ力調查報告書 (1998 2001 年度) (高柣成紀編), pp.29-39. 岩 手県生活環境部自然保護課, 盛岡.

18. Maruyama N and S Nakama. 1983. Block count method for estimating serow population. Jpn J Ecol 33: 243-251.

19. 環境庁. 1979. 第 2 回自然環境保全基礎調查動物分布調查報告書 (哺 乳類）全国版. 財団法人日本野生生物研究センター，東京.

20. 環境省自然環境局生物多様性センター. 2004。種の多様性調查哺乳 類分布調査報告書. 東京.

21. Oka T, Miura S, Masaki T, Suzuki W, Osumi K, Saitoh S. 2004. Relationship between changes in beechnut production and Asiatic black bears in Northern Japan. J Wildl Manag 68: 979-986.

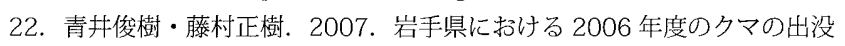
状沉とその対応及び問題点. JBN 緊急クマシン永ジウム\&ワークショッ プ報告書, pp.25-28.
23. 三浦慎悟. 1999. 野生動物の生態と農林業被害 共存の理論を求めて.

（社）全国林業改良普及協会, 東京.

24. Boulanger J, McLellan BN, Woods JG, Proctor MF, Strobeck C. 2004. Sampling design and bias in DNA-based capture-mark-recapture population and density estimates of grizzly bears. $J$ Wildl Manag 68: 457-469.

25. Mowat $G$ and Strobeck C. 2000. Estimating population size of grizzly bears using hair capture, DNA profiling, and mark-recapture analysis. $J$ Wildl Manag 64: 183-193.

26. Poole KG, Mowat G, Fear DA. 2001. DNA-based population estimate for grizzly bears Ursus arctos in northeastern British Columbia, Canada. Wildl Biol 7: 105-115.

27. Woods JG, Paetkau D, Lewis D, McLellan BN, Proctor M, Strobeck C. 1999. Genetic tagging of free-ranging black and brown bears. Wildl SoC Bull 27: 616-627.

28. 高柳敦. 2007. クマ類一放獣とモニタリング. 哺乳類科学, 47:143-144.

29. 三浦慎悟, 大井 徹, 堀野眞一. 2002. 五葉山におけるシ力の個体 群管理の到達点と課題（2001 年度）。五葉山のシ力調査報告書（高槻成 紀編), pp.8387。岩手県環境生活部自然保護課, 盛岡。

30. 坂田宏志, 濱崎伸一郎, 岸本真弓, 三橋弘宗, 三橋西紀, 横山真 马, 三谷雅純. 2001. 兵庫県に扔けるニホンジカの生息密度指標と捕獲 圧，農業被害の関連. 人と自然 $12: 6372$.

31. 濱崎伸一郎, 岸本真弓, 坂田宏志. 2007. ニホンジカの個体数管理 にむけた密度指標 (区画法, 蕒塊密度, 目撃効率) の評価. 哺乳類科学 47: 6571 .

32. 山内貴義, 工藤雅志, 高槻成紀. 2007. 岩手県におけるニホンジカ の保護管理の現状と課題. 哺乳類科学 47:39-44.

33. 野生動物保護管理事務所. 2006. 二ホンジ力の農林業被害対策基礎 調查報告書. 野生動物保護管理事務所, 東京.

34. 横山典子, 濱崎伸一郎, 瀧井暁子, 岸本真弓, 清野紘典, 阿部匡寛. 2006. 人里周辺を利用するニホンジカの行動特性と利用環境. 日本哺乳 類学会 2006 年度大会講演要旨集, pp.39. 